\title{
We Can Handle It: Advocating in Support of State Legislation of Legal Sports Gambling post-Murphy v. NCAA
}

\author{
Daniel J. Spitz and Ryan P. Terry*
}

\begin{abstract}
Post-PASPA (Professional and Amateur Sports and Protection Act of 1992), more than 20 states have either implemented or successfully passed legislation allowing their citizens to gamble on sports. These legislative efforts have created an opportunity for states to capture some of the more than $\$ 150$ billion that Americans annually wager through illegal means. While Nevada has successfully regulated sports gambling for more than 70 years, the Supreme Court's Murphy v. NCAA decision has spurred calls for uniform federal legislation. Central to this push for a federal framework are the leaders of the major sports leagues and their claim of concern for contest integrity. Our position is that this argument is tenuous at best. Rather, we believe this to be a convenient avenue for the major sports leagues to become involved in the regulatory process and secure additional revenue via integrity fees for providing data to federally mandated sources. Further, we argue that this framework of requiring states to use certified data sources that originate from the leagues themselves is not only economically damaging for potential sportsbook operators but could actually result in a greater chance of contest corruption rather than increased integrity.

This article examines the contrasting views of the major North American professional and amateur sports leagues (NHL, NFL, NBA, MLB, and NCAA) with respect to the new, legalized sports gambling environment. We then look at the argument of maintaining contest integrity, which is focal to proposed federal frameworks. Finally, we advocate for a state framework and demonstrate why states are in a better position to regulate sports gambling without federal interference, as state legislation already provides a mechanism by which income from wagers can be redistributed toward improving local infrastructure and funding social welfare programs; under proposed federal legislation, this revenue would divert elsewhere.
\end{abstract}

\footnotetext{
* Daniel J. Spitz, JD, is a professor in the Department of Business Administration at Santa Barbara City College and an adjunct instructor in the Department of Finance and Department of Television and Film at California State University, Los Angeles. His research interests include digital media regulation, sports law, and entertainment law.Email: dspitz@pipeline.sbcc.edu and dspitz@,calstatela.edu

Ryan P. Terry, PhD, is an assistant professor in the Department of Management and Marketing at Texas A\&M University-Corpus Christi. His research interests include talent management, strategic human resource management, and employee mobility. Email: Ryan.Terry@tamucc.edu
} 


\section{Introduction and Procedural History}

On May 14, 2018, the United States Supreme Court deemed the Professional and Amateur Sports and Protection Act of 1992, otherwise known as PASPA, to be unconstitutional. ${ }^{1}$ In a 6-3 majority opinion, Justice Alito wrote:

The legalization of sports gambling requires an important policy choice, but the choice is not ours to make. Congress can regulate sports gambling directly, but if it elects not to do so, each State is free to act on its own. Our job is to interpret the law Congress has enacted and decide whether it is consistent with the Constitution. PASPA is not. ${ }^{2}$

The Court further reasoned that the federal government may not "command the States' officers, or those of their political subdivisions, to administer or enforce a federal regulatory program." ${ }^{3}$

By striking down the law, each state can now propose and implement legislation at the state level for the first time in a generation. The major implication of PASPA's repeal is that it allows casinos and state governments to recapture a portion of the surplus held by illegal offshore companies to a legal market that is expected to contribute an estimated \$22.4 billion dollars annually to US GDP. ${ }^{4}$

Congress enacted PASPA "to stop the spread of State-sponsored sports gambling." ${ }^{5}$ Both states, as well as private individuals, ${ }^{6}$ were prohibited under PASPA from authorizing sports gambling operations "in which amateur or professional athletes participate." 7 Prior to its repeal, PASPA had exempted certain states (Nevada, Delaware, Oregon, and Montana) that had already regulated a sports gambling scheme between January 1, 1976, and August 31, $1990 .^{8}$

Having failed to enact a framework before the passage of PASPA, New Jersey voted in favor of an amendment to its constitution ${ }^{9}$ to provide for sports gambling at casinos and racetracks in $2011 .{ }^{10}$ Following this amendment, New Jersey passed a comprehensive sports wagering act in 2012, which-despite

\footnotetext{
1 See Justia. US Supreme Court. "Murphy v. National Collegiate Athletic Association, 584 U.S. 138 S. Ct. 1461, 200 L. Ed. 2 d 854 (2018)”. (See: Annotation: Primary Holding). https://supreme.justia.com/cases/federal/us/584/16-476/\#tab-opinion-3901188 (May 14, 2018).

2 Id. See Majority Opinion, Alito.

3 Id. See also Printz v. United States (1997), 521 U.S. 898, 935.

4 See Oxford Economics: Economic Impact of Legalized Sports Betting, at p. 5. American Gaming Association. https:/www.americangaming.org/wp-content/uploads/2018/12/AGA-Oxford-Sports-Betting-Economic-Impact-Report1-1.pdf (May 2017).

5 See Senate Report. S. Rep. No. 248, 102d Cong., 1st Sess. 4 (1991).

${ }^{6} 28$ U.S.C. $\$ 3702(2)$

${ }^{7} \mathrm{Id}$.

828 U.S.C. $\$ 3704(a)(1)(2)$. See Govtrack - Congress / Bills / S. 474 (102nd)/ Text: Professional and Amateur Sports Protection Act. https:/www.govtrack.us/congress/bills/102/s474/text.

9 N.J. Const. Art. IV, §7, Para. 2(D), (F).

10 See Tribune News Services. Chicago Tribune. "New Jersey Voters Endorse Making Sports Betting Legal.” https:/www.chicagotribune.com/sports/ct-xpm-2011-11-08-chi-new-jersey-votersendorse-making-sports-betting-legal-20111108-story.html. (November 8, 2011).
} 
overwhelming public support at the state level—was thwarted by the four major professional sports leagues and the National Collegiate Athletic Association (NCAA).$^{11}$ In February 2013, these leagues were collectively successful in persuading a judge to enjoin New Jersey from issuing sports betting licenses. In that case (NCAA v. Christie), the district court ultimately determined that the federal government was constitutionally permitted to regulate sports gambling under its Commerce Clause powers. ${ }^{12}$

Recognizing that this ruling could create a federal monopoly on legal sports betting, then-governor Chris Christie appealed the decision to the Third Circuit. On appeal, New Jersey conceded that the Supremacy Clause of the Constitution gives federal legislation preemptive authority over similar state law, but that $\$ 3702(1)$ of PASPA was unconstitutional and violated the 10th Amendment's anti-commandeering principle. ${ }^{13}$ The anti-commandeering doctrine, which New Jersey relied on throughout the case, states that the federal government cannot require states to adopt or enforce federal law. ${ }^{14}$ This doctrine has been used successfully with the Supreme Court to challenge and strike down federal law in cases where state sovereignty is at issue.

However, in a divided 2-1 panel, the Court of Appeal for the Third Circuit affirmed $^{15}$ the district court's ruling, stating that New Jersey was not required to expend any funds or take any affirmative steps to enact, maintain, or enforce federal law. ${ }^{16}$ In its decision, the Third Circuit emphasized that "statutes prohibiting the states from taking certain actions have never been struck down" under the anti-commandeering rule. ${ }^{17} \mathrm{New}$ Jersey subsequently petitioned the Supreme Court to hear the case via writ of certiorari in June 2014, which was rejected. ${ }^{18}$

Later in 2014, New Jersey's legislature once again passed a bill that purported to partially repeal the state's prohibition on sports gambling as it pertained to casinos and racetracks. ${ }^{19}$ Recognizing this law, which authorized sports gambling, as an attempt to circumvent the Third Circuit's decision, the NCAA and joining parties once again filed suit. Despite the Third Circuit affirming its earlier ruling against New Jersey, the Supreme Court granted a hearing on the case in June

\footnotetext{
11 See Spoto, Mary Ann. Nj.com. “Sports Betting Backed by N.J. Voters”. https://www.nj.com/ news/2011/11/nj_residents_vote_on_legalizin.html (November 9, 2011, updated March 30, 2019).

12 See Nat'l Collegiate Athletic Ass'n v. Christie, 61 F. Supp. 3d 488 (D.N.J. 2014).

13 See Brief for the United States as Amicus Curiae. Nos. 16-476 and 16-477. SCOTUSblog Supreme Court of the United States. https://www.scotusblog.com/wp-content/uploads/2017/05/16476-16-477-CVSG-Christie-AC-Pet.pdf.

14 See Schwinn, Steven. SCOTUSblog - Supreme Court of the United States Blog. "Symposium: It's time to abandon anti-commandeering (but don't count on this Supreme Court to do it." https:// www.scotusblog.com/2017/08/symposium-time-abandon-anti-commandeering-dont-count-supreme-court/. (August 17, 2017).

${ }_{15}$ See NCAA v. Governor of N.J., 730 F. 3d 208, 226-237 (3d Cir. 2013), (cert. denied, 134 S. Ct. 2866 (2014).

${ }^{16}$ Id. at $231-232$.

17 Ibid.

${ }^{18} I d$.

19 See S2640, 216th Leg. (N.J. 2014) (the "2014 Act”). Pet. App. 218a-222a.
} 
2017. During oral arguments, New Jersey once again attempted to persuade the Court that PASPA violated the anti-commandeering principle because there was no meaningful difference between a legislature enacting a law or prohibiting a state legislature from doing so. ${ }^{20}$

The anti-commandeering doctrine was argued successfully in New York $v$. United States, where the Supreme Court held that a provision of the Low-Level Waste Act of 1985 exceeded Congressional authority and violated the 10th Amendment. As a result, the provision was severed from the rest of the Act, as Justice Sandra Day O' Connor reasoned that it "would commandeer state governments into the service of federal regulatory purposes, and for this reason be inconsistent with the Constitution's division of authority between federal and state governments." ${ }^{21}$ Similarly, in Printz v. United States, the federal government was found to have violated the 10th Amendment when Congress required state officers to enforce federal law by conducting background checks on prospective gun owners. ${ }^{22}$ Again, the Supreme Court used the anti-commandeering argument to sever the provision from the Brady Handgun Violence Prevention Act, citing that under the 10th Amendment, the states "retained a residual and inviolable sovereignty ... in which the State and Federal governments exercise concurrent authority" with one another. ${ }^{23}$

Relying on the precedents of New York and Printz, New Jersey argued that PASPA is similarly flawed. Specifically, New Jersey argued that PASPA improperly regulates a state's exercise of its lawmaking power by prohibiting it from modifying or repealing its laws concerning sports gambling. ${ }^{24}$ This time, the Supreme Court agreed with New Jersey, stating that "PASPA's provision prohibiting state authorization of sports gambling schemes violates the anti-commandeering rule." ${ }^{25}$ Having found that "there is no distinction between compelling a state to enact legislation and prohibiting a state from enacting new laws," PASPA was found to have exceeded congressional authority under Article I, and was deemed unconstitutional. ${ }^{26}$ After seven years of challenges in court, state-sponsored sports gambling was finally a reality.

The Court's decision was readily embraced by the American Gaming Association (AGA), which estimates that Americans wager approximately \$150 billion

\footnotetext{
${ }^{20}$ See Oyez. "Murphy v. National Collegiate Athletic Association.” https://www.oyez.org/cases/2017/16-476.

21 See New York v. United States (1992), 505 U. S. 144, 146, 112 S. Ct. 2408.

22 See Printz v. United States, 521 U.S. 898 (1997). See also Gregory v. Ashcroft, 501 U. S. 452, 461 (1991) (“" [T]he States retain substantial sovereign powers under our constitutional scheme, powers with which Congress does not readily interfere.”).

23 Id. at 899.

${ }^{24}$ See Justia. US Supreme Court. "Murphy v. National Collegiate Athletic Ass'n, 584 U.S. _-_-" (2018). (See Majority Opinion, Alito) [citing National Collegiate Athletic Ass'n. v. Christie, 926 F. Supp. 2d, 551, 561-562 (D.N.J. 2013)]. https://supreme.justia.com/cases/federal/us/584/16476/\#tab-opinion-3901188 (May 14, 2018).

${ }^{25} \mathrm{Id}$.

${ }^{26} I d$.
} 
dollars on sports annually, ${ }^{27}$ most of which occur through illegal, offshore betting sites. With less than $\$ 5$ billion dollars in wagering coming through regulated sports books in Nevada, ${ }^{28}$ it is estimated that the repeal of PASPA could generate an additional $\$ 22.4$ billion dollars in annual domestic economic impact. ${ }^{29}$

Following the Court's ruling in Murphy et. al. v. NCAA et. al., any state can now legalize and implement a sports gambling regime. Since each state is either adopting legislation at its own pace or choosing to keep it illegal, this article will advocate for state regulation as the preferred method of enforcement. In doing so, we will examine concerns of the future integrity of sports as well as the diverging viewpoints of each of the five North American major and amateur professional sports leagues.

\section{Stakeholder Approaches to Legalized Sports Gambling}

Each of the four major professional sports leagues as well as the NCAA have taken differing, even self-contradictory approaches historically toward the legalization of sports gambling. That said, there is a growing movement among the leagues toward gambling at the state level.

\section{A. National Hockey League (NHL)}

In 2012, NHL commissioner Gary Bettman noted in a deposition that the atmosphere the NHL wanted to create at games was inconsistent with sports betting and suggested that fans would be more likely to experience cognitive dissonance in such an environment. ${ }^{30}$ As commissioner, Bettman was an instrumental figure in lobbying for the passage of PASPA in 1992. ${ }^{31}$ His position has since changed. At the AGA's sports betting conference in 2018, Bettman noted that the NHL's recent partnership with William Hill Sportsbook "provides a tremendous opportunity to further fan support" and that sports gambling "is another point of engagement for the fans." 32

The NHL has become the first of any major professional sport to install sports books in its arenas, with companies like FanDuel and William Hill Sportsbook

\footnotetext{
${ }^{27}$ See Pempus, Brian. CardPlayer.com. "Federal Sports Betting Ban Overturned By Supreme Court; Online Poker to Benefit.” https://www.cardplayer.com/poker-news/22785-federal-sportsbetting-ban-overturned-by-supreme-court (May 14, 2018).

${ }^{28} I d$.

${ }^{29}$ See Oxford Economics at pp. 5, 8. American Gaming Association. "Economic Impact of Legalized Sports Betting”. https://www.americangaming.org/wp-content/uploads/2018/12/AGA-Oxford-Sports-Betting-Economic-Impact-Report1-1.pdf. (May 2017).

${ }^{30}$ See Bonesteel, Matt. The Washington Post. “The NHL's Gary Bettman was a sports gambling skeptic. Now he's a convert." https:/www.washingtonpost.com/sports/2019/03/28/nhls-gary-bettman-was-sports-gambling-skeptic-now-hes-convert/. (March 28, 2019).

${ }^{31}$ See Brennan, John. NJonlinegambling.com. "NHL's Bettman Completes 180-Degree Turn on Sports Betting”. https:/www.njonlinegambling.com/nhl-bettman-embraces-sports-betting/. (November 6, 2018).

${ }^{32} \mathrm{Id}$.
} 
advertising throughout the game. ${ }^{33}$ The league has also taken the approach that sports gambling will make the game more accessible for non-fans ${ }^{34}$ and cause ratings to go up with its U.S. television partner, NBC.

The NHL's progressive approach has already demonstrated increased fan engagement. Last year, the eventual Stanley Cup Champion St. Louis Blues became the first NHL team to unveil a free, real-time predictive gaming platform during the 2019 playoffs called Enter the Zone. ${ }^{35}$ Enter the Zone gave fans the opportunity to make wagers based on in-game statistics, such as the number of saves made and the first team to register a certain number of shots. Fans who made winning predictions earned points that could be exchanged for prizes, including signed merchandise and season tickets. Results of Enter the Zone exceeded the NHL's expectations, with $70 \%$ of all users playing the game multiple times and $30 \%$ of all users playing in 12 of the 13 playoff games in which the app was offered. ${ }^{36}$ The franchise and the NHL recognized the likelihood of legalized gambling in Missouri and found a way to engage fans early.

With the success of Enter the Zone, the Blues have received calls from teams in every major professional sport. Matt Gardner, vice president for digital media and emerging technology for the Blues said, "Predictive gaming and sports betting are on everyone's radar right now." ${ }^{37}$ Sara Slane, vice president of public affairs for the AGA noted, "In-play proposition betting is going to be the most impactful marketing tool that the sports industry has seen from a fan engagement perspective ... [with] people consuming sports for a larger period of time." ${ }^{38}$ Now that the NHL's restrictions against sports gambling have been lifted, the league sees predictive gaming as a way to enhance the in-arena experience and grow the game with new fans.

\section{B. National Football League (NFL)}

Christopher Halpin, the NFL's executive in charge of strategy, remarked in September 2019 that the league already has great fan engagement, and that "we don't need to integrate sports betting directly into that." ${ }^{39}$ However, under a legal sports betting regime, the NFL projects to earn $\$ 2.3$ billion annually in additional revenue, by far the most of any of the four major professional North

\footnotetext{
${ }^{33} I d$.

${ }^{34}$ William Hill has reported that its wagers on NHL games have increased $38 \%$ in Nevada since the repeal of PASPA.

${ }^{35}$ See St. Louis Blues / Press Release. NHL.com. "Introducing Enter the Zone - the real-time prediction game". https://www.nhl.com/blues/news/introducing-enter-the-zone---the-real-timeprediction-game/c-307326448. (May 10, 2019).

${ }^{36}$ See Wyshynski, Greg. ESPN. "How the Blues' predictive gaming app reveals the future of NHL gambling”. https://www.espn.com/nhl/story/_id/28212395/how-blues-predictive-gaming-app-reveals-future-nhl-gambling. (4 December 2019).

${ }^{37} \mathrm{Id}$.

${ }^{38} I d$.

39 See Draper, Kevin. New York Times. "Sports Betting Has Arrived to Transform the N.F.L. Or Not.". https://www.nytimes.com/2019/09/04/sports/football/sports-betting-nfl.html. (September 4, 2019).
} 
American sports leagues. ${ }^{40}$ This increase is primarily due to projected growth in sponsorship rights, media rights, merchandise sales, and ticket sales, with television advertising from gambling services and money flowing directly from betting operators to the league being listed as the largest subcomponents of increased revenue. ${ }^{41}$

With the 2019-20 NFL season serving as the first season for legal wagering, sports betting services have already reported strong consumer interest relative to the prior season. ${ }^{42}$ For instance, FanDuel has reported a $1200 \%$ increase in spending by its users through its online platform, and rival DraftKings, Inc. has reported a $200 \%$ increase in bets to the same day a year earlier, with its site traffic increasing by $65 \%$ year-to-year. ${ }^{43}$ In addition, the AGA has previously reported that $19 \%$ of NFL fans already gamble on games, using either offshore accounts or illegally with bookies; an additional $31 \%$ of football fans, representing nearly 38 million people and $15 \%$ of all U.S. adults expect to bet on games post-legalization. ${ }^{44}$

Perhaps the NFL's prior stance against sports gambling is derived from its position that sports gambling should be regulated federally by Congress rather than left to the individual states. Commissioner Roger Goodell has noted that Congress should enact uniform standards for states that plan to legislate sports betting to ensure fans have access to official, reliable league data and to enable law enforcement with the resources, monitoring, and enforcement tools to protect fans and penalize bad actors at home and abroad. ${ }^{45}$ However, Goodell seems to overlook the efficacy of private business to accomplish the task of producing reputable, reliable data to its users. The AGA's Sara Slane notes that "agreements between sports leagues and the gaming industry enable all sports stakeholders to work together to eliminate the illegal sports betting market." ${ }^{46}$

After being an opponent of sports gambling for many years, the NFL now seems to embrace it. In its new collective bargaining agreement (CBA), the NFL is allowing sports gambling in its stadiums and plans to share revenues

\footnotetext{
${ }^{40}$ See American Gaming Association/The Nielsen Company (US), LLC. https://www.americangaming.org/sites/default/files/Nielsen\%20Research\%20-\%20All\%204\%20Leagues\%20FINAL. pdf (2018).

${ }^{41} I d$.

42 See Kerber, Ross. Reuters. “Online Sports Betting Sites Score as NFL Season Gets Under Way". https://www.reuters.com/article/us-usa-gambling-nfl/online-sports-betting-sites-score-asnfl-season-gets-under-way-idUSKCN1VU2AZ. (September 9, 2019).

${ }^{43} \mathrm{Id}$.

${ }^{44}$ See Isidore, Chris. CNN Business. "NFL could pocket billions from coming boom in sports gambling". https://money.cnn.com/2018/09/05/news/companies/nfl-sports-gambling-revenue/index.html. (September 5, 2018).

${ }^{45}$ See Parry, Wayne. USA TODAY. "Goodell details NFL's stance on sports gambling after ruling”. https://www.usatoday.com/story/sports/nfl/2018/05/21/goodell-details-nfls-stance-on-sports-gambling-after-ruling/35185425/. (May 21, 2018).

46 See Ramsey, Eric. Legal Sports Report. "MLB Makes MGM Resorts 'Official Gaming Partner' As Sports Betting Deals Proliferate". https://www.legalsportsreport.com/26238/mlb-sports-betting-announcement-mgm/. (November 27, 2018).
} 
generated "by the operation of gambling-related businesses located in or physically attached to an NFL Stadium." ${ }^{, 47}$ Revenue from wagers on any aspect of NFL games, individual player performances, and other NFL/club-related activity is also part of the CBA, which runs through $2030 .{ }^{48}$ Overall, the NFL has started to warm up to the idea of the new sports gambling regime, which should fuel its domestic popularity and lead fans to sports books across the country to wager on its games.

\section{National Basketball Association (NBA)}

Similar to the NHL and NFL, the NBA has changed its tone significantly regarding its approach to sports gambling. In 2007, amidst an ongoing referee scandal, NBA Vice President Rick Buchanan stated, "The harms caused by government endorsement of sports betting far exceed the alleged benefits. ${ }^{, 49}$ However, in 2014, NBA Commissioner Adam Silver exclaimed in an editorial that "sports betting should be brought out of the underground and into the sunlight where it can be appropriately monitored and regulated." 50

In his op-ed contribution, Silver noted sports betting "is a thriving underground business that operates free from regulation or oversight" ${ }^{\prime 1}$ and with few legal options available, individuals desiring to bet must resort to illicit bookmaking operations or offshore websites. Silver's statements, which advocated for a federal framework to be adopted by Congress ${ }^{52}$ represented the first voice in favor of sports betting of any major professional sport in North America. Silver specifically lobbied for monitoring and reporting of unusual betting-line movements to track the integrity of wagers, licensing of betting operators to ensure their legitimacy, and minimum-age verification measures as key components of a federal framework. ${ }^{53}$ Rather than rely on Congress to adopt a uniform approach, many of the goals proposed by Silver can be adopted and enforced at the state level by the same bureaus and commissions that regulate gaming and licensing.

While Silver has spoken to a primary concern for the transparency and integrity of wagering, statements by others within the NBA suggest this would come at a cost. Dan Spillane, assistant general counsel and senior vice president for the

\footnotetext{
${ }^{47}$ See Purdum, David. ESPN. "New CBA allows owners, players to cash in on stadium sportsbooks".

https://www.espn.com/chalk/story/_id/28930507/new-cba-allows-owners-players-cash-stadiumsportsbooks (March 20, 2020).

${ }^{48} I d$.

49 See Purdum, David. ESPN. "I'm not pro sports gambling. I'm just a realist.". https://www.espn. com/chalk/story/_id/12262502/gambling-issue-adam-silver-wants-sports-gambling-legalized-other-leagues-join-him. (February 1, 2015).

${ }^{50}$ See Silver, Adam. New York Times. "Legalize and Regulate Sports Betting”. https://www. nytimes.com/2014/11/14/opinion/nba-commissioner-adam-silver-legalize-sports-betting.html (November 13, 2014).

${ }^{51} \mathrm{Id}$.

${ }^{52} I d$.

${ }^{53} \mathrm{Id}$.
} 
NBA, told a New York state Senate subcommittee in 2018 that the league would be justified in receiving a cut of the wagers placed on professional basketball in the form of an integrity fee. Spillane suggested that this additional revenue- $1 \%$ of the handle - would be needed for the NBA to monitor and investigate bets as well as educate the public (the NBA has since dropped its integrity fee request to $0.25 \%){ }^{54}$

Conversely, sportsbook operators have taken issue with the concept of integrity fees. MGM CEO Jim Murren said, "[we] believe we are paying for that already, in the relationships we have, the money we are paying for data and the money we are paying for sponsorships." ${ }_{55}$ Additional costs, even a 1\% percent integrity fee, is estimated to equate to $20 \%$ or more of a sportsbook's profits. ${ }^{56}$ Connecticut Rep. Joe Verrengia has noted that states are "not for legislation that ... would line the pockets of MLB, NBA, or any other major sports owners." 57 To date, no state that has passed sports gambling laws has provided for an integrity fee.

\section{Major League Baseball (MLB)}

In the wake of the infamous 1919 Black Sox scandal, then-Commissioner Kenesaw Mountain Landis - who was also a federal judge-implemented Rule 21 in the official rules of baseball, which explicitly banned betting by anyone in connection with a game. ${ }^{58}$ Rule 21 was later used in 1989 to ban all-time hits leader Pete Rose for life for illegally wagering on games while playing and managing the Cincinnati Reds. It should come as no surprise, then, that MLB would be particularly sensitive to issues of game integrity within an expanded environment of legalized sports wagering.

Like the NBA, MLB has requested that that sports gambling legislation include a $0.25 \%$ integrity fee when people bet on its games. ${ }^{59}$ However, unlike the NBA - and other sports leagues - MLB has been progressive in its stance on sports gambling, seeing it as a "great source of fan engagement." ${ }^{60}$ MLB Com-

\footnotetext{
${ }^{54}$ See Drew, James. The News TRiBune. "Major League Baseball wants cut of the action if Washington legalizes sports gambling”. https://www.thenewstribune.com/news/state/washington/ article236014943.html. (October 11, 2019).

${ }_{55}$ See Derbyshire, Martin. PlayUSA - US Online Gambling News. "Missouri Has A Better Idea Than Paying Sports Betting Integrity Fees”. https://www.playusa.com/missouri-sports-betting-integrity-fees/ (December 4, 2018, updated January 4, 2019).

${ }^{56} \mathrm{Id}$.

${ }^{57}$ See Schult, Steve. CardPlayer - Home: Poker News. “Connecticut Sports Betting Bill First To Contain Integrity Fee." https://www.cardplayer.com/poker-news/23714-connecticut-sports-betting-bill-is-first-to-contain-integrity-fee (March 13, 2019).

58 See Rule 21(d)(2): Gambling. Major League Baseball. “Rule 21 - Misconduct”. http://content. mlb.com/documents/8/2/2/296982822/Major_League Rule 21.pdf.

59 See Drew, James. The News Tribune. "Major League Baseball wants cut of the action if Washington legalizes sports gambling”. https:/www.thenewstribune.com/news/state/washington/ article236014943.html. (October 11, 2019).
}

${ }^{60}$ See Ryan, Greg. Sports Business: Boston Business Journal. “'I'm a realist': MLB boss Manfred on sports gambling, Disney and Trump.” https://www.bizjournals.com/boston/ news/2019/03/06/mlb-s-boss-on-sports-gambling-disney-and-trump.html. (March 6, 2019). 
missioner Rob Manfred originally advocated for a uniform federal framework, ${ }^{61}$ but recognized that "the federal government wasn't going to get there in time, and the states were going to proceed." ${ }^{\prime 2}$ Understanding this, MLB Executive Vice President of Gaming Kenny Gersh stated that the league is "lobbying ... [to] have every state to get bills passed. ${ }^{63}$ MLB further recognized that while each state's gambling regime will be different, within five years sports gambling will be widespread. ${ }^{64}$

Manfred further acknowledged his support for legalized sports gambling, stating that baseball has an advantage for gamblers due to the "opportunity to be creative with the types of sports wagers" that could be made in between plays. ${ }^{65}$ In response to the Supreme Court's decision, MLB has already entered into partnerships (like the NHL and NBA) with MGM Resorts and DraftKings ${ }^{66}$ to ensure its readiness for various proposition (in-game) bets.

\section{E. Amateur Sports - NCAA}

The NCAA remains against any form of sports gambling. Specifically, the NCAA's official "Don't bet on it" stance on sports gambling remains staunchly opposed to "all forms of legal and illegal sports wagering, which has the potential to undermine the integrity of sports contests and jeopardizes the welfare of student-athletes and the intercollegiate athletics community." ${ }^{67}$ The NCAA takes this position primarily to preserve the impartiality of its games, stating "the spread of legalized sports wagering is a threat to the integrity of athletic competition and student-athlete well-being." 68

However, the NCAA's basic position seems to have little to do with integrity, and everything to do with control. Currently, the NCAA holds a near-monopoly over the revenue generated from its games. Even some of its member schools have implemented policies in line with the NCAA's strong opposition to sports gambling after individual states have begun to legalize it. For instance, Purdue

\footnotetext{
${ }^{61} I d$.

62 Id.

${ }^{63}$ See Berra, Lindsay. Baseball America. “A Major Gamble: MLB Embraces Sports Betting”. https://www.baseballamerica.com/stories/a-major-gamble-mlb-hopes-legalized-sports-bettingwill-engage-new-fans/ (June 11, 2019).

${ }^{64} I d$.

${ }^{65}$ See Kasabian, Paul. Bleacher Report. “Rob Manfred Says Slower Pace of Play in MLB Favors Creative Gambling Wagers". https://bleacherreport.com/articles/2808110-rob-manfred-says-slower-pace-of-play-in-mlb-favors-creative-gambling-wagers. (November 27, 2018).

${ }^{66}$ See Ramsey, Eric. Legal Sports Report. "MLB Makes MGM Resorts 'Official Gaming Partner' As Sports Betting Deals Proliferate”. https:/www.legalsportsreport.com/26238/mlb-sports-betting-announcement-mgm/. (November 27, 2018).

${ }^{67}$ See Home $>>$ Enforcement. NCAA. "Sports Wagering”. http://www.ncaa.org/enforcement/ sports-wagering.

${ }^{68}$ See Pierce, Charles P. Sports Illustrated. "Like Most Sports Controversies, the Supreme Court Gambling Case is About Money and Control". https://www.si.com/2017/12/05/nfl/supreme-courtsports-gambling-christie-ncaa. (December 5, 2017).
} 
University in Indiana approved a policy prohibiting faculty, staff, and non-athlete students from gambling on sports events involving any Purdue teams, coaches, or student-athletes, with penalties ranging from discipline to termination. ${ }^{69}$ Purdue's policy comes in response to the state of Indiana legalizing sports gambling in September of 2019. ${ }^{70}$ The enforceability of such a policy remains equivocal while the spirit of the rule is clearly indicative of the NCAA's historic position on the matter.

The NCAA remains against the expansion of legalized sports gambling while the four major professional sports leagues have grown to favor it. While each league takes a different approach to this new environment, a commonality is the desire to ensure game integrity. Proponents of a federal framework to regulate sports gambling argue that the federal government is in a better position to do this. Previous federal proposals have stipulated that fees would be required to maintain the integrity of contests and wagers. States, on the other hand, have not included such language in their legislation because it would likely result in financial benefits to the sports leagues at the expense of funding their own state programs. The remainder of this article advocates for a state-sanctioned sports gambling framework.

\section{The Fallacy of Federal Integrity}

At the heart of the argument for a federal framework for sports betting is maintaining the integrity of the contests on which wagers are placed. Indeed, the word integrity appears in the title of the most recent federal proposal and is the focus of several sections within the bill. ${ }^{71}$ Yet, there is little evidence that contest integrity is at risk. Furthermore, while Congressional findings highlight the vast discrepancy in annual legal vs. illegal sports wagers made by Americans ( $\$ 5$ billion vs. $\$ 150$ billion, respectively) - and admit this discrepancy was likely caused by previous efforts by the federal government to curtail sports gambling — none of the findings highlight a problem with contest integrity. ${ }^{72}$

In advocating for federal oversight, NFL Executive Vice President Jocelyn Moore has stated that "without continued federal guidance and oversight, we are very concerned that sports leagues and state governments alone will not be able to fully protect the integrity of sporting contests and guard against the harms Congress has long recognized as being associated with sports betting." ${ }^{.73}$ In addition, the United States Tennis Association is concerned with "compliance

\footnotetext{
${ }^{69}$ See Rollock, Alysa C. Purdue University. "Purdue trustees approve sports wagering policy". https://www.purdue.edu/newsroom/releases/2019/Q4/purdue-trustees-approve-sports-wagering-policy.html. (October 10, 2019).

70 See NBC Chicago. “Sports Betting Is Now Legal In Indiana”. https://www.nbcchicago.com/ news/local/indiana-legalizes-sports-betting-559167941.html. (September 2, 2019).

71 See 115th Congress. Congress.gov. "S.3793 - Sports Wagering Market Integrity Act of 2018”. https://www.congress.gov/bill/115th-congress/senate-bill/3793/text.

${ }^{72} \mathrm{Id}$.

${ }^{73} \mathrm{Id}$.
} 
and cooperation with fifty separate sets of regulations and regulators," 74 but is primarily concerned with protecting the integrity of the game.

Federal legislation proponents treat sports wagering differently than casino gambling primarily because the focal contest takes place in a separate location where oversight becomes more difficult. ${ }^{75}$ However, sports contests are not unlike other interstate activities that have succeeded without federal regulation such as horseracing, lotteries, and multi-state progressives. ${ }^{76}$ While there is little debate that corruption in sport exists, recent research suggests that it is less pervasive in the US than previously reported. ${ }^{77}$ Even if sports gambling were regulated exclusively by the states, the federal government retains the authority to investigate sports corruption. ${ }^{78}$

A proposed federal framework provision to battle corruption is to initially mandate that sports wagering operators determine outcomes with the use of data from the "applicable sports organization; or an entity expressly authorized by the applicable sports organization," 79 which may be problematic. First, any data source has the potential of being hacked and the entire market could become crippled if a single data source is being used ${ }^{80}$ due to a federal mandate. Second, a single data source provides an opportunity for moral hazard, whereby bad actors may have greater incentive to provide false data on particular events. A data monopoly allows for a greater opportunity of corruption-particularly match fixing and potentially even ghost fixing - to occur. ${ }^{81}$ Without such mandate, sports wagering operators may purchase data from a variety of sources. This not only creates a marketplace, but prior research has shown that corruption can be mitigated by using multiple, independent data collectors. ${ }^{82}$

\footnotetext{
${ }^{74}$ See Smith, Gordon A. United States Tennis Association. Senate Democrats. https://www.democrats.senate.gov/imo/media/doc/12.19.18\%20USTA\%20Letter\%20of\%20Support.pdf (December 19, 2018).

${ }^{75}$ See Roberts, Jennifer \& Gemignani, Greg (“Roberts \& Gemignani”). Who Wore it Better? Federal v. State Government Regulation of Sports Betting, 9 UNLV Gaming L.J. 77, 90 (2019).

${ }^{76} \mathrm{Id}$.

${ }^{77}$ See Berkowitz, Jason P., Depken II, Craig A. \& Gandar, John M. Market evidence against widespread point shaving in college basketball, 153 Journal of Economic Behavior and Organization, 283-292 (2018).

${ }^{78}$ See Roberts \& Gemignani, supra note 75, at 90.

79 See 115th Congress. Congress.gov. "S.3793 - Sports Wagering Market Integrity Act of 2018." https://www.congress.gov/bill/115th-congress/senate-bill/3793/text.

${ }^{80}$ See Holden, John \& Schuster, Mike. The Sham of Integrity Fees in Sports Betting, 16 NYU J. LAW \& BusinEss 31, 49 (2019).

${ }^{81}$ See Holden, John T. Ghosts in the Machine: How Corrupters Manipulate Games that Never Happened, 22 Gaming L. Rev. 633 (2018). "Ghost fixing" is the practice of creating data for a fake game. See also Paul Kelso, FIFA haunted by new gambling phenomenon: 'ghost games,' THE TELEGRAPH. https://www.telegraph.co.uk/sport/football/international/8835176/Fifa-haunted-bynew-gambling-phenomenon-ghost-games.html (2011).

${ }^{82} \mathrm{Id}$.
} 


\section{Advocating for a State Framework}

Research firm Gambling Compliance predicted in 2017 that more than 20 states would sanction sports wagering by 2025 if the Supreme Court nullified PASPA. ${ }^{83}$ Following the decision, it is clear this estimate was conservative, at best. As of the end of 2019, 14 states have already implemented or legalized sports gambling in some form (online, in-person, or both). An additional seven states having passed bills awaiting implementation and 24 others are moving in the direction of legalization. ${ }^{84}$ Currently, only a handful of states nationwide are yet to introduce legislation legalizing sports gambling. ${ }^{85}$

At the federal level, there is a concerted bipartisan effort to address sports gambling, with Ret. Sen. Orrin Hatch (R-UT) and Sen. Charles Schumer (D-NY) proposing the Sports Wagering Market Integrity Act of $2018 .{ }^{86}$ Since its introduction, the bill has been read twice and referred to the Committee on the Judiciary, ${ }^{87}$ suggesting that any federal legislation will have to supplement, if not supersede, existing state law. This approach will certainly result in a similar constitutional argument that New Jersey successfully used in Murphy v. NCAA-that the federal law violates the anti-commandeering provision of the 10th Amendment by forcing states to adopt and adhere to its law instead.

Unsurprisingly, both consumers and the AGA have indicated a strong preference for state-level sports gambling. Pursuant to AGA-commissioned research by the Mellman Group, every major demographic, education level, race, gender, and political affiliation strongly prefers state and tribal government regulation, with $66 \%$ of those surveyed in favor versus only $17 \%$ preferring federal regulation. ${ }^{88}$ Slane further notes that "the results of this research are overwhelmingly clear: consumers ... believe it should be regulated by state ... governments." 89

Legal Sports Betting notes that in the first 18 months following the repeal of PASPA, states had already received more than $\$ 100$ million dollars in tax

\footnotetext{
83 See King, Bill. Street \& Smith's Sports Business Journal. “After Supreme Court hearing, it's anyone's bet on sports gambling”. https://www.sportsbusinessdaily.com/Journal/ Issues/2017/12/11/Law-and-Politics/Gambling.aspx?hl=after+supreme + court + hearing\&sc $=0$. (December 11, 2017).

${ }^{84}$ See Rodenberg, Ryan. ESPN.com. "United States of Sports Betting: An Updated Map of Where Every State Stands". https://www.espn.com/chalk/story//id/19740480/the-united-states-sportsbetting-where-all-50-states-stand-legalization. (August 2, 2019, updated December 30, 2019).

${ }^{85} \mathrm{Id}$.

${ }^{86}$ See 115th Congress. Congress.gov. "S.3793 - Sports Wagering Market Integrity Act of 2018". https://www.congress.gov/bill/115th-congress/senate-bill/3793/text. (2018).

${ }^{87} \mathrm{Id}$.

${ }^{88}$ See The Mellman Group. "Sports Betting in 2019: Overwhelming Public Support For Legal Sports Betting Markets”. https:/www.americangaming.org/wp-content/uploads/2019/01/Mellman-Group-Research-Deck.pdf. (January 2019).

${ }^{89}$ See Press Release. American Gaming Association. "Sports Betting in 2019: Americans Overwhelmingly Support Legal Sports Gambling”. https://www.americangaming.org/new/sports-betting-in-2019-americans-overwhelmingly-support-legal-sports-betting/. (January 30, 2019).
} 
revenue. ${ }^{90}$ Since each state currently regulates its industry independently, the associated tax rates vary significantly. For instance, Nevada taxes its wagers at $6.75 \%$ of its casinos and books' sports betting revenue, whereas Pennsylvania taxes sports betting at 36\%. ${ }^{11}$ Smaller markets such as Rhode Island and Delaware tax their books at over $50 \% .{ }^{92}$ New Jersey, by contrast, has set two tiers of taxation: one for in-person wagering $(8 \%)$ and one for online wagering $(13 \%),{ }^{93}$ making it the only state to currently distinguish between the two.

This control over the taxation rates allows states to supplement their general fund with revenue from wagering, which can then be allocated and redirected toward funding education, building infrastructure, and furthering health services departments. Some states, such as Mississippi, Pennsylvania, and Arkansas, take things a step further by providing a percentage to the counties and municipalities that host the sportsbook itself. ${ }^{94}$ Missouri has proposed that taxation revenue from sportsbooks be used to create an Entertainment Facilities Infrastructure Fund that can be used to pay for the construction and maintenance of various entertainment, cultural, and recreational facilities across the state. ${ }^{95}$ Missouri's law calls for a $14 \%$ tax on adjusted gross revenues and operator application fees as key components of raising capital for this fund. ${ }^{96}$ Overall, the ability for each state to apportion funds where it deems most necessary is a desirable effect of the tax revenue received from sports wagering.

Conversely, at the federal level, there is no provision drafted within the Sports Wagering Market Integrity Act that addresses redistributing wagering income to the states or allocating revenue to fund specific needs. Rather, the excise tax revenue derived from wagering will not be distributed on a pro-rata share with each state, and instead be directed toward law enforcement and programs for the prevention and treatment of gambling disorders ${ }^{97}$ Under a federal framework, it is unclear exactly how much revenue states would receive under this bill to fund social programs and local infrastructure projects, if any.

Proponents of federal regulation suggest that there could be a greater, negative impact on game and wager integrity if state regulation persists. Yet, there is no evidence that state-level regulation of sports gambling is any less reputable than its proposed federal counterpart. Indeed, regulation of sports gambling in

\footnotetext{
${ }_{90}$ See Legal Sports Betting Revenue Tracker. Legal Sports Betting.com. https://www.legalsportsbetting.com/regulated-sports-betting/. (Updated November 4, 2019).

${ }^{91} I d$., at Sports Betting Tax Revenue.

${ }^{92} \mathrm{Id}$.

${ }^{93} \mathrm{Id}$.

${ }^{94} \mathrm{Id}$.

${ }_{95}^{5}$ See Derbyshire, Martin. PlayUSA - US Online Gambling News. "Missouri Has A Better Idea Than Paying Sports Betting Integrity Fees". https://www.playusa.com/missouri-sports-betting-integrity-fees/ (December 4, 2018, updated January 4, 2019).

${ }^{96} \mathrm{Id}$.

${ }^{97}$ See Senate Democrats. "Schumer, Hatch Introduce Bipartisan Sports Betting Integrity Legislation". https://www.democrats.senate.gov/newsroom/press-releases/schumer-hatch-introduce-bipartisan-sports-betting-integrity-legislation. (December 19, 2018).
} 
Nevada has been a success and has been credited with maintaining sports integrity by identifying point-shaving schemes on multiple occasions. ${ }^{98}$

A related concern for integrity involves the lack of uniformity between states adopting sports gambling measures. In Europe, however, cooperation agreements made up of the public and private sectors that span national borders have made match-fixing identification relatively straightforward. ${ }^{99}$ Much like states in the US, the gambling laws of European nations differ considerably to reflect their respective values and priorities. However, sharing information through trade groups like the European Gaming and Betting Association and the European Sports Security Association have preserved the integrity of sports contests. ${ }^{100}$

Finally, there is little support for the contention that fees associated with federal proposals would result in increased game and/or wager integrity. Rather, betting records have historically been the most reliable indicator of match-fixing and abuse of inside information, ${ }^{101}$ with the majority of successful prosecutions for match-fixing coming from such information. States can task their gaming commissions with overseeing abnormal betting patterns through analysis of this data and work directly with the major sports leagues in this effort, should they be willing to cooperate without a fee for their efforts to uphold the integrity of their respective sport. Overall, an integrity fee serves to make the leagues more profitable, but comes at an increased expense to sportsbooks, who will then pass the cost of doing business onto its consumers and businesses. As a result, it is likely that an integrity fee will make it more difficult for legitimate sportsbooks to compete with illegal, offshore books. ${ }^{102}$

Moreover, the leagues itself are better positioned to address issues of match fixing than Congress. Between 1995-2001, the NCAA's Eligibility Committee specifically dealt with 29 cases of sports gambling by student-athletes ${ }^{103}$ and implemented stronger penalties for schools and individuals who break its rules. Professional and amateur sports leagues have had systems in place for decades to monitor such nefarious activity and it is unclear how fees within the Sports Wagering Market Integrity Act would go beyond this.

Finally, the preamble to the federal Sports Wagering Market Integrity Act acknowledges that "all forms of gaming have historically been regulated at the State level, and legal sports wagering markets are and should be established and

\footnotetext{
98 See Holden, John T. Regulating Sports Wagering, 105 Iowa L.R. 575, 597-598 (2020).

99 See Minton, Michelle ("Minton"). Competitive Enterprise Institute. "Legalizing Sports Betting in the United States: A Playbook for State Liberalization and Regulation No. 243”. https://cei. org/sites/default/files/Michelle $\% 20$ Minton $\% 20$ - $\% 20$ Legalizing $\% 20$ Sports $\% 20$ Betting $\% 20 \mathrm{in} \% 20$ the $\% 20$ United $\% 20$ States $\% 20 \% 281 \% 29$.pdf (March 15, 2018).

$100 \mathrm{Id}$.

101 See Ross, Stephen F. and Anderson, Adrian. Street \& Smith's Sports Business Journal.

"Strong Regulation Could Inject Integrity Into Sports Gambling”. https://www.sportsbusinessdaily.com/Journal/Issues/2015/02/16/Opinion/Ross-Anderson.aspx. (February 16, 2015).

102 See Minton, supra note 99, at 17.

103 See Claussen, Cathryn L. and Miller, Lori K. The Gambling Industry and Sports Gambling: A Stake in the Game?, 15 Journal of Sports Management, 350, 360 (2001).
} 
regulated principally by the States." 104 To address this, the Sports Wagering Market Integrity Act includes the idea of a National Sports Wagering Commission to oversee and set standards for wagering; however, its role is not spelled out in the body of the proposed law itself. ${ }^{105}$

The goal of any centralized sports gambling framework should be the redistribution of wagers to the states and its stakeholders. Setting a mandatory integrity fee, which is more likely under a federal framework, serves to primarily benefit the NHL, NFL, NBA, and MLB; yet the leagues itself play no functional role in regulating the sports gambling industry. ${ }^{106}$ Acceptance of an integrity fee would provide the leagues with a financial windfall while diverting that same revenue away from funding state programs. ${ }^{107}$ Since states will be managing sportsbooks under their gaming commissions, they are best suited to distribute its earnings.

\section{Summary}

Overall, while the Sports Wagering Market Integrity Act continues to be debated and amended, states are continuing to move forward with legislating sports gambling operations. Stakeholders who once shunned the idea have since recognized that the immediate future and profitability of sports gambling lies in state-level regimes. Growing public support further supports the contention that state governments are more trustworthy and better equipped to regulate this market. Moreover, federal legislation has remained stagnant relative to state law. The implication of passing uniform, federal law in the future is that Congress will likely have to grandfather in permission for states who have approved preexisting sports betting through a carve-out in the law. ${ }^{108}$ Furthermore, the latest provisions of a federal framework are contradictory to the central argument of a need to maintain contest integrity by proposing a mechanism, which provides opportunities for moral hazard and increased corruption in sports. ${ }^{109}$

Finally, we have already seen a number of states eager to pass laws in jurisdictions where federal law had previously prevented it. These states now have the unique opportunity to set taxation rates and stimulate employment at casinos and in-arena sportsbooks to grow its economy. So far, the results are clear. We are

\footnotetext{
104 See Wood, Joss. PlayUSA.com. "Federal Government Wants a Piece of Sports Betting Action, Says Sen. Hatch”. https://www.playusa.com/federal-government-legal-sports-betting/. (October 18, 2018, updated February 15, 2019).

105 Id.

106 See Legal Sports Report. “Sports Betting Integrity Fee”. https://www.legalsportsreport.com/ integrity-fee/ (updated August 2, 2019).

107 See Holden, John T. and Schuster, W. Michael. New York University Journal of Law And Business. "The Sham of Integrity Fees in Sports Betting (abstract)". https://papers.ssrn.com/sol3/ papers.cfm?abstract id=3360659 (April 25, 2019).

108 See Wood, Joss. PlayUSA.com. "Federal Government Wants a Piece of Sports Betting Action, Says Sen. Hatch”. https://www.playusa.com/federal-government-legal-sports-betting/. (October 18, 2018, updated February 15, 2019).

109 See Holden, supra note 81.
} 
already seeing states tax handles on sportsbook operators, oversee results, and earn revenue. This revenue, under state control, is being redirected and properly allocated toward vital social and infrastructure programs rather than through a federal formula that primarily benefits the sports leagues. By contrast, an integrity fee remitted to the leagues is a false narrative to divert funds away from state programs. It is for these reasons that state-sponsored sports gambling is the preferred method of oversight: they can handle it. 